Syifa Al-Qulub 4, 2 (Januari 2020): 11-20

Website: journal.uinsgd.ac.id/index.php/syifa-al-qulub

ISSN-25-8453 (online) dan ISSN-2540-8445 (cetak)

\title{
RELIGIOUS EPISTEMOLOGIS: EVIDENTIALISME DAN EKSKLUSIVISME HUMANIST
}

\author{
Muliadi \\ UIN Sunan Gunung Djati Bandung \\ Email: Khalef1muliadi@yahoo.com/Muliadi1@uinsgd.ac.id
}

\begin{abstract}
This article seeks to explain about the spiritual model as an effort that is passed and taken by humans in understanding and achieving Something Absolute, namely God. The method used is reflective analysis, which describes deeply and comprehensively the potential inherent in human beings that is used in understanding the existence of self and God. Human definitions are very diverse, including: socio-political beings, thinking beings, sentient beings, even godly beings. All of these definitions reinforce that humans are creatures. While the object sought by humans is something that is outside and inside him. In its search, humans exploit the potential of knowledge inherent in themselves, starting from the simplest with empirical experience, then rationalist knowledge, to religious-spiritualist knowledge. With the perfection of potential and knowledge achieved, human beings are placed in two functions that must not be broken, namely to strengthen their pertical and horizontal relationships. This pertikal relationship is a form of exclusivity with his Lord, while his horizontal form is sincere dedication because he is with his fellow humans and his nature.
\end{abstract}

Keywords:

Epistemology, evidentalis, spirituality, religions, and humanity.

\begin{abstract}
Abstrak
Artikel ini berupaya menjelaskan tentang model spiritual sebagai usaha yang dilalui dan ditempuh manusia dalam memahami dan mencapai Suatu Yang Absolut, yaitu Tuhan. Metode yang digunakan adalah analisa reflektif, yaitu mendeskripsikan secara mendalam dan menyeluruh potensi yang melekat pada diri manusia yang dipakai dalam memahami eksistensi diri dan Tuhannya. Depinisi manusia sangat beragam, diantaranya: mahluk sosialpolitik, mahluk berpikir, mahluk perasa, bahkan mahluk bertuhan. Seluruh depinisi ini menguatkan bahwa manusia sebagai mahluk pencari. Sedangkan objek yang dicari oleh manusia adalah sesuatu yang berada di luar dan di dalam dirinya. Dalam pencariannya, manusia memanfaatkan potensi pengetahuan yang melekat pada dirinya, mulai dari yang paling sederehana dengan pengalaman empiris, kemudian pengetahuan rasionalis, sampai pada pengetahuan religious-spiritualis. Dengan kesempurnaan potensi dan pengetahuan yang dicapainya, manusia ditempatkan pada dua fungsi yang tidak boleh diputus, yaitu menguatkan hubungan pertikal dan horisontalnya. Hubungan pertikal ini adalah bentuk eksklusifitas dengan Tuhannya, sementara bentuk horisontalnya adalah pengabdian yang tulus karenaNya dengan sesama manusia dan terhadap alamnya.
\end{abstract}

Kata kunci:

Epistemologi, evidentalis, spiritualitas, agama, dan kemanusiaan.

DOI: http://dx.doi.org/10.15575/saq.v4i2.7574

Received: 2020-01-22; Accepted: 2020-01-23 ; Published: 2020-01-29 


\section{A. PENDAHULUAN}

Aliran dalam epistemologi yang pertama lahir dan berkembang seiring dengan pertumbuhan dan kemajuan diri manusia adalah empirisme. Sebelum otak manusia berpungsi, panca inderalah yang menemani dan menjadi sandaran pengetahuan manusia semenjak dilahirkan di dunia ini. Keyakinan kaum empiris bahwa, pengetahuan berasal dari serapan indera manusia, sementara otak hanya sebagai penyimpan tangkapan data tersebut yang datang dari indera manusia. Untuk itu, pengetahuan yang paling benar adalah yang empiris dan yang empiris adalah pengetahuan atau kebenaran yang sesungguhnya, bisa dipercaya, dan bisa diandalkan oleh seorang individu. Landasan dasar sebagai pijakan para kaum empiris yaitu asumsi bahwa manusia sebagai "tabula rasa atau kertas kosong" yang pada perjalanan sejarah eksistensi manusia di alam ini berusaha mengisi lembaran tersebut melalui berbagai pengalaman dan serapan yang ia torehkan dan kreasikan. Akhirnya, apa yang kita sebut sebagai sebuah kebenaran adalah sebuah pengalaman, pengalaman yang empiris dan lahir dari sebuah serapan panca indera.

Pengalaman empiris memberikan pengaruh yang amat kuat dan besar terhadap perkembangan dan pertumbuhan manusia, baik secara fisik maupun psikis. Apa yang paling diingat oleh seseorang dalam hidupnya adalah sederetan pengalaman dari masa anak-anaknya sampai ia berada dalam moment-moment penyusunan riwayatnya. Pengalaman masa kecil ketika diasuh oleh orang yang sangat dicintai atau sebaliknya ketika terjadi kekerasan dalam hidup seorang anak merupakan pengalaman yang akan diingat dan susah untuk dihapus dalam sejarah hidup, bahkan sampai seseorang akan menjemput akhir hidupnya. Seperti itulah kehebatan dan kekuatan pengalaman empiris manusia, maka sangat wajar kalau kita mengatakan, bahwa kualitas dan profesionalitas seseorang sangat ditentukan oleh pengalamannya.

Dalam sejarah hidup manusia, otak dengan kelebihan yang melekat pada dirinya, ingin melampaui pancaindera. Rasionalitas manusia kemudian menjadikan serapan data-data yang datang dari pengalaman empiris, mengalami pengolahan yang kemudian dijadikan sebagai bahan pijakan dalam memutuskan berbagi persoalan yang kemungkinan akan terjadi di masa yang akan datang. Spekulasi komulatif ini adalah solusi antisipasif apabila terjadi sebuah kemiripan dari sebuah pengalaman yang sudah terjadi sebelumnya. Jelas bagi kita, bahwa premispremis yang dijadikan pijakan dalam rasionalisme merupakan sebuah pengalaman (experience).

Sementara rasionalisme memiliki slogan, yaitu sebuah fakta dianggap benar, apabila memiliki kesesuaian dengan akal sehat. Sebuah objek, meskipun menurut penserapan pancaindera adalah sebuah fakta empiris, tetapi, bagi rasio, fakta tersebut masih bisa diragukan kebenarannya apabila akal sehat tidak menerimanya. Sesuatu yang masuk akal adalah kebenaran dan sebaliknya. Ungkapan ini adalah pijakan yang tidak boleh digugat.

Dalam perjalanan hidup, sikap maupun cara berpikir kita yang empiris dan rasionalis banyak memiliki benturan. Ungkapan yang sering kita dengar seperti "kenyataan tidak seindah seperti yang dipikirkan atau apa yang dipikirkan tidak seindah kenyataan" adalah pelajaran bahwa pengalaman empiris yang mengandalkan pengalaman memiliki banyak kelemahan, kekurangan, bahkan kesalahan. Begitu juga halnya dengan pemikiran yang selalu mengandalkan standar rasionalitas memiliki banyak sisi yang tidak bisa diterima oleh pengalaman hidup kita. Rasionalitas yang mengandalkan validitas akal sehat justru menjadi bahan empuk skeptisisme. Rasionalitas yang irrasional banyak kita dapatkan dalam kehidupan.

Kelemahan yang terdapat pada empirisme dan rasionalisme seperti yang dipaparkan di atas kemudian melahirkan aliran baru sebagai penyempurna dari kedua aliran di atas, yaitu Positivsme. 
Aliran ini mengasumsikan bahwa pengetahuan itu berasal dari panca indera dan akal sehat. Kedua sumber pengetahuan tadi saling melengkapi sehingga pengetahuan yang dihasilkan bisa terukur validitasnya baik secara empiris maupun rasionalis yang berujung pada hasil yang positifis.

Kembali pada wacana (discourse) epistemologi. Kalau kita berbicara mengenai satu bagain dari filsafat ini, maka seperti yang telah dipaparkan di atas, beberapa variabel berikut harus menjadi perhatian, yaitu: terkait dengan sumber pengetahuan dengan segala aliran yang terkait di dalamnya (source of knowledge), karakteristik dasar yang ada pada ilmu tersebut (nature of knowledge), dan validitas atau keabsahan menurut pandangan ilmu atau pengetahuan (validity of knowledge). ${ }^{1}$

Wilayah epistemologi tidak hanya terbatas pada pemenuhan konsepsi yang bersifat rasional, empiris ataupun positivistik semata, tetapi harus melalui penelusuran sampai pada tingkat yang lebih tinggi yaitu perjalanan spiritual yang bersifat rohani atau ilahi. Empirisme, rasionalisme, dan positivisme ketiganya dijadikan sebagai tangga menuju prisip yang paling dasar, yaitu pribadi suci "manusia sebagai tabula rasa". Dengan menggapai makom tersebut, seseorang akan menemukan sesuatu Yang Tidak Terbatas (The Infinite atau The Ultimate).

Karena alasan tersebutlah, maka iluminasionisme memiliki sikap yang berbeda. Iluminasionisme menyandarkan diri pada rasa (dzauq). Ia merupakan sumber pengetahuan yang bersandarkan pada feeling atau perasaan. Intuisi merupakan bagian yang sangat vital yang terdapat pada diri manusia yang bisa memberikan pengetahuan secara langsung. Itulah alasan mengapa Henri Bergson

\footnotetext{
1 . Milton D. Hunnex, Chronological And thematic Chart of Philosophies And Philosophers, Michigan: Chandler Publishing Company, 1986, hIm. 9
}

(1859-1941) seorang filsuf asal Perancis sangat mengagungkan sisi ini daripada empiris dan rasionalis. ${ }^{2}$

Akan seperti apa, kalau model epistemologi tersebut berhadapan dengan dimensi keberagamaan atau agama (religions)? Keberagamaan yang penulis maksudkan disini adalah pemikiran dan pemahaman serta sikap kita terhadap "agama".

\section{B. PEMBAHASAN}

Pernyataan atau pertanyaan yang sering dilontarkan bukan hanya para penganut rasio, tetapi juga datang dari kaum empiris sebagai sikap kritis mereka terhadap agama adalah: apakah agama itu adalah sesuatu yang masuk akal? (is belief in God rational?). Para evidentialist akan menjawab secara objektif "tidak", karena fakta untuk hal tersebut tentunya kurang atau sangat minim (lack of evidence). Mereka yang menjawab "ya" tentunya menganggap bahwa bukti rasional maupun empiris sangat cukup untuk mendukung pendapat atau pengakuan mereka (sufficient evidence). Ada juga kelompok yang tidak membutuhkan fakta maupun alasan rasional untuk percaya kepada Tuhan. Tuhan tidak perlu dibuktikan dan Tuhan tidak perlu untuk dibuktikan (evidence is not necessary).

Menanggapi pernyataan atau pertanyaan di atas, maka, kita harus kembali pada diri kita, atau pengalaman hidup keberagamaan masing-masing dari diri kita. Jawaban dari pertanyaan inipun pasti akan sangat partsial dan subjektif, karena kemampuan otak manusia sangat beragam, begitupula dengan pengalaman keberagamaannya.

Puluhan, ratusan, bahkan ribuan alasan bisa didatangkan oleh manusia untuk mengatakan bahwa tidak cukup bukti dan alasan untuk mengantarkannya bisa percaya pada Tuhan. Fenomena-fenomena

\footnotetext{
2 .Titus, Smith, Nolan, terj. Persoalan-Persoalan Filsafat, Jakarta: Bulan Bintang, 1984, hlm. 204-206
} 
dalam sejarah para Nabi dan Rosul telah banyak mencatat hal tersebut baik yang datang dari lawan dan musuh maupun yang datang dari keluarganya sendiri. Nabi Musa dengan Fir'aun dan antek-anteknya, nabi Nuh dengan anaknya sendiri, dan nabi Muhammad dengan para kaum kafir Qurays. Semuanya telah membuktikan, bahwa alasan maupun fakta-fakta yang mendukung untuk pengakuan terhadap Tuhan tidak mampu dan tidak bisa menjadikan seseorang bahkan suatu kaum untuk percaya kepada Tuhan.

Sebaliknya, tidak harus ribuan, ratusan, bahkan puluhan, satu fakta pun sudah cukup sebagai alasan bagi seseorang untuk menundukkan wajahnya kehadapan Yang Maha Kuasa. Umumnya di kalangan akdemisi, beberapa fakta dan alasan dideskripsikan dengan luas dan mendalam untuk mendukung alasan-alasan yang menguatkan secara rasional dan empiris kepercayaan terhadap Tuhan.

Sebuah contoh dari pengalaman Nabi Ibrohim sebagai bapak monotheistik. Upaya pencarian sebab atau penggerak pertama sebagai "Tuhan" tidak berhenti pada matahari yang ia kagumi dan agungkan. Rasionya tidak bisa menerima bahwa matahari sebagai sebab pertama dan sebab terakhir dari segala yang ada dan semua peristiwa yang terjadi di alam ini. Gambaran dari cerita Nabi Ibrohim ini, menyimpulkan bahwa, akal manusia tidak akan memberikan informasi yang memuaskan bila agama atau Tuhan dilihat atau ditrawang dari kacamata rasio.

Proses peristiwa yang dijalani oleh Nabi Ibrohim juga bisa kita sejajarkan dengan kisah Nabi Musa yang menggambarkan keinginan beliau untuk melihat Allah. Mereka menemukan jawaban dari kegelisahan rasionalitas mereka tentanNya justru dengan meninggalkannya dan menempuh jalan keislaman (islam), yaitu kepasrahan dengan mengatakan (wa ana min almuslimin).

Menyimpan rasionalitas dan empiris inderawi serta mengedepankan pengalaman spiritual (spiritual experience) adalah jalan yang pernah ditempuh oleh para Nabi dan auliya dari beragam agama. Hal ini, juga banyak dikembangkan oleh para pemikir tasawuf abad Pertengahan, seperti Ibn Arobi dalam Fusus alHikamnya, Surowardi dengan Hikmat alIsyroqnya, Mulla Sadra dengan Hikmah alMuta'aliyahnya dan lain-lain. Bahkan gen dari pemikiran tersebut dapat kita temukan pada masa filsafat Islam klasik, yaitu dari Al-Farabi dengan konsep emanasinya (alfaidhiyah). Pada abad ModernKontemporer, model seperti yang dikembangkan oleh para tokoh tadi tadi memiliki banyak pengikut, seperti filosof tradisionalis Sayyid Husein Nasr, maupun dari kalangan psikologi religious yang umum, seperti yang dikembangkan oleh Danah Zohar dan Ian Marshall, dan banyak lagi tokoh-tokoh lain.

Sayyid Husein Nasr, The Garden of Truth: The Vision and Promise of Sufism, Islam's mystical Tradision, 2007, menggambarkan seorang nabi (prophet) sebagai Universal Man (al-fitrah) yang pada dan dalam dirinya terdapat Self Knowledge. ${ }^{3}$ Dengan berada pada maqom 'alim, ma'lun, dan 'ilm atau 'arif, ma'ruf dan ma'rifah, maka seorang individu secara otomatis telah melampaui dimensi empiris-rasionalis, masuk dengan fananya pada dimensi cahaya atau realitas ketuhanan (Divine Reality) yang tak terbatas dan tak terhingga (The Infinite and Ultimately). Realitas empiris dan pikiran (mind) adalah dua hal yang menjadi penghalang dan penghambat bagi manusia atau individu yang merindukan dimensi ini. Untuk itu, seseorang yang ingin menggapai maqom tersebut hendaknya menjaga atau menjauhi gangguangangguan yang bersifat empiris yang bisa mengotori jiwanya, serta pemikiranpemikiran yang dapat menghambat

\footnotetext{
3 . Sayyid Husein Nasr, The Garden of Truth: The Vision and Promise of Sufism, Islam's mystical
} Tradision, USA: HarperCollins Publisher, 2007, 20-21 
jiwanya dalam fokus menuju "kesatuan" atau "percintaan"denganNya.

Paradigma-paradigma modernkontemporer telah mengganti posisi dominasi scientific yang dulu pernah menguasai dunia dengan slogan empirisme-rasionalistik ke paradigma baru, yaitu paradigma estetik dan paradigma "pertumbuhan" (psikologi evolusioner).

Paradigma estetik, seperti yang dikembangkan oleh Mark C. Taylor dan H.G. Gadamer, telah banyak menarik perhatian para peminat dan pemerhati psikologi, agama, dan budaya. Kedua tokoh ini melihat, bahwa seluruh realitas adalah sebagai sebuah ekspresi dengan proses kreatifitas yang sangat luar biasa. Realitas menurut mereka bukan semata sebuah permainan, melainkan sebuah kreativitas yang amat serius. Untuk itu, dalam memahami realitas ini, tidak hanya melalui proses empiris-rasionalis, tetapi harus melampaui keduanya. Karena realitas sebagai objek adalah sesuatu yang sangat istimewa dan sangat luar biasa, sekaligus menggambarkan sesuatu di baliknya (behind it), maka subjek dan objek menjadi hal yang terkait secara otomatis dan tak terpisahkan (inner-outer). Pada dimensi inilah, kemudian agama menjadi sesuatu yang amat penting. Menurut mereka, Tuhan adalah Totalitas Energi dan hal terpenting lain dari agama adalah ritual. Ritual adalah bentuk tertinggi dari agama, disini, yang paling dipentingkan bukan nalar, tetapi imajinasi dan perasaan.

Selain kedua tokoh di atas, Thomas More, dalam bukunya Care of Soul, menunjukkkan bagaimana ia sangat menaruh perhatian pada dimensi spiritual atau ruhani. Ia membagi dimensi manusia kepada tiga wilayah, yaitu: Tubuh (body), pikiran (mind), dan ruh (soul). Pembagian ini kemudian diikuti oleh pemetaan wilayah pengetahuan secara otomatis, yaitu: teknologi, ilmu dan filsafat (science and philosophy), dan seni dan agama (aesthetic and religion). Menurutnya, wilayah yang pertama memiliki karakter, yaitu fisik. Ia menuntut kebutuhan yang segera atau harus terpenuhi secara memadai dan memiliki sifat yang sangat pasif, untuk itu, medan atau sesuatu yang sangat atau yang paling menyenangkan baginya adalah teknologi.

Sementara pikiran (mind) menurut More, yaitu sesuatu yang mengambil jarak dengan apa yang dipikirkannya. Karena adanya jarak tersebut, maka secara otomatis membutuhkan waktu. Hal yang paling menonjol dari fungsi pikiran adalah pembenaran (correctness). Sesuatu yang tidak masuk dalam kategori akal adalah sesuatu yang melawan atau melanggar aturan dan pikiran tidak akan menerima hal yang demikian. Dengan fungsi utamanya tersebut, akal kemudian merambat pada fungsi bawaannya, yaitu sebagai alat untuk memecahkan berbagai persoalan (problem solver). Dengan akal yang melekat pada diri manusia, maka ia digelari dengan sebutan animale rasionale (hewan yang berakal). Akal inilah kemudian yang menjadi kesepakatan dikalangan para ilmuan bahkan masyarakat awam sekalipun, yang membedakannya dari mahluk-mahluk ciptaan Tuhan yang lain. Karena fungsinya yang sangat sentral pada diri manusia, maka tidak salah kalau akal kemudian menjadi titik tolak penghargaan pada manusia. Dengan mines keberfungsianya pun ikut menjadi standar kadar penghargaannya, sebagai contoh, manusia yang kehilangan akalnya akan dibebaskan dari tuntutan kasus hukum.

Berbeda dari kedua dimensi di atas. Jiwa (ruh/soul) menurut More, memiliki karakter yang berbeda. Pancaran darinya adalah sikap yang memiliki kecondongan untuk saling menghormati. Orang yang memiliki spirit atau jiwa yang baik akan sangat gampang dan secara suka rela menghormati sesama ciptaanNya, baik dari kalangan binatang dan tumbuh-tumbuhan, apalagi di kalangan sesama manusia. Selain itu, sikap mengagumi juga melekat pada seorang pribadi yang memiliki karakter jiwa yang baik, menghargai 
kreatifitas yang dihasilkan orang lain dan jauh dari sikap mencemooh dan mencela sesuatu yang berada di luar dirinya.

Sabar juga bagian dari hal yang melekat pada soul ini. Orang yang melekat pada dirinya sifat ini, tidak akan mudah tersulut api amarah tidak akan tergesa-gesa atau ceroboh dalam mengambil sikap atau tindakan yang bisa mendatangkan dampak negatif baik bagi dirinya pribadi, keluarganya, maupun orang yang berada di sekelilingnya. Sabar adalah sifat yang sangat mulia yang dimiliki oleh jiwa yang baik. Dengan sifat ini, seseorang melangkah pada sifat mulia berikutnya, yaitu kearifan. Kearifan atau kebijaksanaan ini kemudian menjadi tujuan akhir dari proses berfilsafat seseoarang. Kemudian sifat terakhir dari jiwa yang memiliki nilai estetis adalah berpetualang. Berpetualang di sini, dalam pengertian yang positif, yaitu jiwa yang selalu berimajinasi dan mengarah ke arah yang Maha Indah.

Selain paradigma estetis seperti yang dipaparkan di atas yang dikembangkan oleh Thomas More, paradigma pertumbuhan yang dikembangkan oleh Danah Zohar dan suaminya Ian Marsal serta Ken Wilber juga mendapatkan perhatian yang tidak kalah hebatnya, terutama di kalangan pemerhati psikologi sufistik. Danah Zohar dan suaminya menulis buku, yaitu SQ: Spiritual Intelligence - The Ultimate Intelligence. Buku ini kemudian diterjemahkan dalam bahasa Indonesia oleh penerbit Mizan satu tahun setelah terbit dalam bahasa aslilnya (SQ: Memanfaatkan Kecerdasan Spiritual dalam Berpikir Integralistik dan Holistik untuk Memaknai Kehidupan). ${ }^{4}$

Menurut Marshall, kecerdasan spiritual merupakan tonggak dasar yang sangat

\footnotetext{
4 . Danah Zohar dan Ian Marshal, SQ: Spiritual Intelligence - The Ultimate Intelligence. Ter. SQ: Memanfaatkan Kecerdasan Spiritual dalam Berpikir Integralistik dan Holistik untuk Memaknai Kehidupan, Bandung: Mizan, 2001
}

fundamental. Dengannya, kecerdasan yang lain akan ikut ditentukan. Ia adalah penentu bagi perkembangan dan pertumbuhan kecerdasan yang lain, yaitu IQ (Intelligence Question), EQ (Emosional Question) dan AQ (Adversity Question). Kecerdasan disini adalah kemampuan dalam melihat makna yang lebih dalam atau yang lebih besar dari kait-mengkainya suatu peristiwa atau segala pengalaman. SQ ini, terkait dengan kesadaran, baik yang bersifat personal, interpersonal, dan transpersonal (The Centre of Self). Ketidakmampuan seseorang untuk masuk pada wilayah superconsciousnes atau transpersonal, yaitu the centre of self (ke kedalaman diri), mengakibatkan seseorang terjebak pada sikap narcisism, megalomania, kecanduan, tidak mampu berempati, depresi, histeris, dan bentuk "ganggual mental" yang lain.

Berbeda dari Marshal, Ken Wilber dengan bukunya yang sekaligus menggambarkan teorinya, yaitu $A$ Theory of Everything memaparkan tingkatan mental manusia, yaitu: pra konvensional, konvensional, dan postkonvensional. Yang pertama bermuara pada egosentris (saya). Yang kedua, bermuara pada sosiosentris (kami), dan yang ketiga bermuara pada worldsentris (kita semua). Dengan tiga tingkatan mental manusia tersebut, maka seharusnya seorang individu harus mengarahkan dirinya pada pemahaman dan sikap yang tidak hanya mengedepankan kepentingan pribadinya, tetapi memberikan segenap kemampuannya dalam mengupayakan kepentingan kebersamaan secara universal.

Selain itu, Wilber juga mengembangkan teori perubahan dengan istilahnya, yaitu SEX (Synergistic, Energy, eXchange). Menurutnya, untuk menuju atau menggapai sebuah perubahan yang mengagumkan, maka yang harus diwujudkan lebih dahulu adalah sinergi, yang menggambarkan suatu kerjasama atau kekompakan antara berbagai elemen yang terkait dan dibutuhkan. Setelah adanya sinergi tersebut, baru elemen 
berikutnya menjadi penting, yaitu energi atau daya yang menjadi dasar atau motor dari perubahan tersebut.

Selain kedua hal di atas, Wilbell juga mengembangkan teori yang tidak kalah penting, yaitu pembagian level agama pada narrow religion dan deep religion. Yang pertama, bisa disamakan dengan istilah eksoteris agama, sedangkan yang kedua adalah esoteris agama. Bagian yang pertama lebih bersifat dan penekanan pada formaliltas keberagamaan dan yang kedua adalah sebaliknya, yang lebih menekankan pada wilayah substansi keberagamaan. Wilayah ini, biasanya melampaui batasbatas fenomena penampakan seraya melangkah lebih jauh, yaitu pada makna konotatif yang tersembunyi atau yang berada di balik makna denotatif.

Dalam ajaran-ajaran lokal (local wisdom), banyak ditemukan konsep atau teori yang disampaikan melalui pesanpesan secara simbol, seperti buah kelapa dan kelopak bunga yang terdiri dari berbagai lapisan. Pada buah kelapa, untuk sampai pada intinya yaitu minyak kelapa, harus melalui sekian banyak proses, yakni: membuang sabut dan batoknya barulah ditemukan isinya. Isinya juga diproses sedeikian rupa baru mendapatkan minyaknya. Dalam proses inipun, terkadang banyak tidak mendapatkan "minyak" seperti yang diharapkan.

Begitu juga dengan kelopak bunga. Untuk sampai pada inti, yaitu "Putik Sari", harus melalui sekian banyak kelopak yang harus dikupas dan dilepaskan. Kedua simbol ini merupakan pelajaran, bahwa manusia, apabila ingin sampai pada "substansi manusia"nya, maka jalan yang ditawarkan oleh kedua simbol tersebut adalah dengan mengupas sisi-sisi diri yang bisa menghambat perjalanan spiritualnya untuk menuju sebuah Kebenaran (alHaqq).

Dalam bentuk praktek-praktek keagamaan yang bersifat ritual, banyak sekali kita temukan ajaran tentang "hakekat diri", terutama di kalangan gerakan-gerakan tarekat yang sangat menjamur di Nusantara ini. Konsep tentang "martabat Tujuh" yang sering kita temukan, merupakan contoh nyata dari wujud ajaran tasawuf di negeri ini.

Dengan pola yang berbeda, namun memiliki penekanan yang sama, yaitu spiritualitas. Menurut James S. Custinger ada tiga kategori kelopok pemerhati agama dengan perbedaan pendekatan yang dipakainya yaitu primitivists, functionalists, dan fideists. ${ }^{5}$ kelompok pertama, melihat agama dari sisi historis, yaitu perkembangan, karakter, dan keterkaitannya dengan variable-vriabel eksternal dan internal agama itu sendiri. Kelompok kedua, melihat agama dari sisi fungsinya. Fungsi agama itu apa? Apakah ia berfungsi seperti materi, teknologi, atau beberapa analogi fungsi yang lainnya. Tetapi, apakah materi, teknologi, dan juga yang lainnya bisa ditempatkan pada "posisi" agama, apabila yang menjadi titikpointnya adalah pada kesamaan fungsi semata? Di sinilah agama hadir dengan ciri khasnya, yaitu sifat sakral, sifat ini tidak dimiliki oleh saint dan teknologi.

Pada bagian ketiga, Cutsinger membentuk empat level. Tingkat pertama diberi label dengan istilah belief, faith, experience, dan transformation. Masingmasing tingkatan ini terkadang menjadikan setiap orang yang berada pada posisi ini merasa memiliki hubungan yang sangat "intim" dengan Tuhannya. ${ }^{6}$ Tingkat pertama seperti "kepercayaan" memiliki semangat dan kekuatan yang berbeda dengan tingkatan yang berada di atasnya yaitu keyakinan. Begitu pula dengan tingkatan berikutnya, yaitu pengalaman yang memiliki beragam ekspresi dan dengan kandungan makna konotatif yang sangat beragam pula. Seperti ungkapan: "aku bertemu dengan Tuhan", "Aku melihat Tuhan", bahkan ada juga

\footnotetext{
${ }^{5}$. James S. Cutsinger, Paths of Return, Lectures on the World's Religions, University of South Carolina, tth, hlm., 12

. Ibid,hlm 12
} 
ungkapan: "aku adalah Kebenaran”, dst. Ungkapan-ungapan ini menunjukkan pengalaman dari masing-masing penganut agama bahkan penganut aliran kepercayaan tertentu yang sangat konotatif dan muncul dari mereka yang telah tercerahkan.

Deskripsi yang dikemukakan oleh Cutsinger di atas menunjukkan bahwa agama itu "bertangga". Semestinya setiap pemeluk agama memahami adanya kondisi tersebut dan menyadari bahwa masingmasing tangga saling membutuhkan secara strukturalis-hirarkis. Fenomena ini telah banyak dikemukakan oleh para tokoh psikologi, misalnya Danah Zohar dan Ian Marshall, ${ }^{7}$ seperti yang telah dipaparkan sebelumnya, maupun para filosof yang berusaha mencari titik temu antara ketiga sisi yang dikemukakan oleh Cutsinger di atas, termasuk Ibn Tufail ${ }^{8}$ dan Ibn Rusd ${ }^{9}$ dari Spanyol.

Kemudian, bagaimana agama yang melekat pada setiap pribadi ini bisa bertransformasi pada wilayah real kehidupan ini? Pada sisi inilah agama akan benar-benar menjadi sesuatu yang ideal tidak hanya yang terkait dengan eskatologis, tetapi juga di sini dan sekarang (dunia).

Pada sisi lain, pandangan bahwa agama adalah sesuatu yang sakral dan eksklusif telah lahir semenjak manusia ada dan ketika ia menganggap bahwa diluar dirinya terdapat sesuatu yang lebih kuat, lebih agung, lebih perkasa, dan lain-lain yang kemudian ikut memberikan pengaruh pada dirinya baik secara langsung maupun tidak langsung. Pada dimensi ini, semua agama menghadirkan dirinya sebagai sesuatu

\footnotetext{
7 . Danah Zohar dan Ian Marshall, SQ: Memanfaatkan Kecerdasan Spiritual dalam Berpikir Integralistik dan Holistik untuk Memaknai Kehidupan, Mizan, Bandung, 2001

8. Abu Bakar ibn Tufail, Hay bin Yaqzan, Beirut, Libanon: Darul al-Masyriq , 1987

9 . Ibn Rusd, Faslu Al-Maqol Fi ma Baina Al-Hikmah Wa Al-Syari'ah Min Al-Ittisol, Kairo: Dar al-Ma'arif, 1983
}

yang eksklusif. ${ }^{10}$ Dalam agama Islam, misalnya ungkapan "sesungguhnya agama yang diridhoi oleh Allah adalah agama Islam", dengan kalimat yang berbeda, tetapi memiliki substansi yang sama, agama-agama yang lain juga mempunyai ekspresi eksklusif yang bermakna ekslusivisme.

Pengakuan terhadap eksistensi agama atau keyakinan yang ada di luar penganut agama tertentu, tidak kemudian menghilangkan rasa dan sikap mengekslusifkan agama sendiri yang bersifat pribadi (privat). Untuk itu, masing-masing pemeluk agama memiliki keharusan menjaga eksklusifisme keberagamaannya. Ada beberapa alasan untuk ini, di antaranya:

1. Sesuatu yang istimewa (ekslusif) itu pasti satu. Dari sekian banyak yang istimewa pasti ada satu yang paling istimewa dari yang istimewa.

2. Dalam Islam, ungkapan " bagimu agamamu dan bagiku agamaku" merupakan gambaran bahwa dialog antar keyakinan (interfaith) mestinya dibagun atas dasar sosial-kemasyarakatan bukan atas dasar keyakinan atau tauhid. ${ }^{11}$ Dialog antar spiritual yang digagas oleh Kautsar juga tidak kemudian menyatukan antara berbagai spiritualist dalam satu kesatuan, tetapi dalam fenomenanya mereka tetap berbeda dan beragam. Bahkan, di antara mereka tetap menganggap satu jalan spiritual memiliki keistimewaan dengan jalan spiritual yang lain. Hal ini bisa

\footnotetext{
${ }^{10}$ Eksklusif (exclusif) adalah istimewa atau keistimewaan. Bukan dalam pengertian politik, yaitu sebagai sebuah sikap politik yang cenderung ke arah sektarian, parokial, formalistik, legalistik yang berlawanan dengan makna substantif atau esensial. Bahtiar Effendy, Teologi Baru Politik Islam: Pertautan Agama, Negara, dan Demokrasi,Yogyakarta: Galang Press, 2001, hlm. 44, 48, 111.

${ }^{11}$. Kautsar Azhari Noer, "Passing Over": Memperkaya Pengalaman Keberagamaan, dalam, Passing Over: Melintasi Batas Agama, Jakarta: Gramedia, 1998, hlm.261-262
} 
dengan mudah kita temukan pada adanya beragam aliran yang terdapat dalam spiritualisme.

3. Dalam sejarah Islam, nabi Muhammad membangun sikap ekslusif pada ummatnya dalam bidang keyakinan atau tauhid lebih lama dan lebih diutamakan dibandingkan membangun hubungan mu'amalahnya baik dengan intern ummat Islam maupun dengan ekstern ummat Islam.

4. Allah menjadikan sesuatu itu berbeda-beda (plural) dan memberikan kelebihan pada masing-masing ciptaannya, termasuk agama (bisa saja Allah menjadikan semua agama menjadi satu dan menjadikan semua ummat agama menjadi satu ummat juga, tapi ini adalah bentuk tamanni yang justru menguatkan bentuk plural (berbedabeda) tersebut).

5. Fenomena pluralitas ini tidak hanya terdapat antar ummat beragama, tetapi juga banyak ditemukan dalam intern ummat beragama. Hal seperti ini juga digambarkan dalam Hadist Nabi Muhammad "perbedaan yang ada dalam ummatku adalah sebuah karunia/ rahmat" (ikhtilafu ummati rohmatun);

6. Manusia itu terbatas. Manusia dari berbagai dimensi adalah mahluk terbatas. Fisiknya terbatas, umurnya terbatas, akalnya terbatas, jiwanya terbatas, rohaninya terbatas, dan lain-lainnya juga terbatas. $^{12}$ Untuk itulah maka ia mengekslusifkan agama (Tuhan) yang memberikan perngaruh terhadap dirinya.

7. Agama hadir dengan memberikan kepastian. Masing-masing agama hadir dengan konsep kepastian yang ia berikan kepada ummatnya. Agama dengan

\footnotetext{
12 . William Barrett, terj., Mencari Jiwa: dari Descartes Sampai Komputer, Yogyakarta: Adipura, 2001, hlm. 127-129. Pada dimensi ini, manusia memiliki sifat yang dikenal dalam Ilmu Kalam, yaitu ja'iz yang bermakna diadakan dan juga bisa ditiadakan oleh Sang Pencipta, sementara Allah bersifat wajib yang Independent dimana Adanya tidak berdasar dari luar diriNya.
}

kesakralannya memberikan sesuatu yang pasti baik pada wilayah-wilayah yang bersifat profan keduniawian maupun pada wilayah ukhrowi-eskatologis. Agama memberikan kepastian tentang Tuhan, surga, neraka, kebahagiaan, dan lainlainnya. Di sinilah agama sangat ekslusif bagi masing-masing pemeluknya.

\section{PENUTUP}

Setelah manusia memahami agama dengan multi paradigma dan multi metode, maka ia memiliki tugas, yaitu berlombalomba dalam menggapai sesuatu yang terbaik dalam versi agama masing-masing. Dalam hubungannya antar ummat beragama adalah membangun kerja sama dalam berbagai bidang yang terkait dengan sosial-keduniawian, bukan dalam bidang ketauhidan, karena ini akan menyentuh privasi dari masing-masing agama yang bersifat eksklusif. Pluralitas dan eksklusifitas adalah suatu keniscayaan, tetapi humanisasi (memanusiakan manusia) sebagai objek tempat pengimplementasian pengabdian semua penganut agama merupakan sebuah kewajiban.

\section{DAFTAR PUSTAKA}

Bakker, J.W.M, Sejarah Filsafat Islam, Kanisius, Yogyakarta 1978.

Barrett, William, terj., Mencari Jiwa: dari Descartes Sampai Komputer, Adipura, Yogyakarta, 2001.

Cutsinger, James S., Paths of Return, Lectures on the World's Religions, University of South Carolina, tth,

Effendy, Bahtiar, Teologi Baru Politik Islam: Pertautan Agama, Negara, dan Demokrasi, Galang Press, Yogyakarta, 2001.

Hunnex, Milton D. Chronological And thematic Chart of Philosophies And Philosophers, Michigan: Chandler Publishing Company, 1986.

Marshall, Danah Zohar dan Ian, SQ: Memanfaatkan Kecerdasan Spiritual dalam Berpikir Integralistik dan Holistik 
untuk Memaknai Kehidupan, Mizan, Bandung, 2001.

Nasr, Sayyid Husein, The Garden of Truth: The Vision and Promise of Sufism, Islam's mystical Tradision, USA: HarperCollins Publisher, 2007.

Noer, Kautsar Azhari, "Passing Over": Memperkaya Pengalaman Keberagamaan, dalam, Passing Over: Melintasi Batas Agama, Gramedia, Jakarta, 1998.

Nolan, Smith, Titus, terj. PersoalanPersoalan Filsafat, Bulan Bintang, Jakarta, 1984.

Rusd, Ibn, Faslu Al-Maqol Fi ma Baina Al-Hikmah Wa Al-Syari'ah Min AlIttisol, Dar al-Ma'arif, Kairo, 1983

Tufail, Abu Bakar bin, Hay ibn Yaqzan, ed, Alber Naser Nadr, cetakan kedua, Darul Masyriq, Bairut, Libanon, 1986. 